\begin{tabular}{c} 
Volume and Issues Obtainable at Center for Sustainability Research and Consultancy \\
Journal of Business and Social Review in Emerging Economies \\
ISSN: 2519-089X (E): 2519-0326 \\
Volume 3: Issue 1 June 2017 \\
CSRᄃ \\
Journal homepage: www.publishing.globalcsrc.org/jbsee \\
\hline
\end{tabular}

\title{
Entrepreneurial Orientation, Technology Orientation and Small and Medium Enterprises Performance in Nigeria: Role of Government Support Policies
}

\author{
${ }^{1}$ Maryam Imam Ibrahim, ${ }^{2}$ Ooi Yeng Keat, ${ }^{3}$ Shamsul Huda Binti Abd Rani \\ ${ }^{1}$ Ramat Polytechnic Maiduguri, Nigeria,botulbe@gmail.com \\ ${ }^{2}$ Universiti Utara Malaysia, Malaysia,ykooi@uum.edu.my \\ ${ }^{3}$ Universiti Utara Malaysia, Malaysiashuda@uum.edu.my
}

\begin{tabular}{l}
\hline ARTICLEDETAILS \\
\hline History \\
Revised format: May 2017 \\
AvailableOnline: June 2017 \\
\\
Keywords \\
Entrepreneurial Orientation, \\
Technology Orientation, \\
Government Support, SMEs \\
Performance, Nigeria.
\end{tabular}

JEL Classification:

L26, L29, O14

\begin{abstract}
Purpose:The study empirically analyzes the moderating role of government support policy on the relationship between entrepreneurial orientation, technology orientation and performance of small and medium enterprises (SMEs) in northeast Nigeria.

Design/Methodology/Approach:The paper adopts quantitative survey method using structured questionnaires; data was collected from 240 SME owner-managers in northeast Nigeria. The data collected was analyzed using Partial Least Squares PLS-SEM.

Findings: The findings of the study indicates a significant positive relationship between EO, TO and Performance of SMEs. Additionally, the outcomes of the study authenticate that government support policy moderates the relationship between EO, TO and performance of SMEs in Nigeria.

Implications/Originality/Value:The study have practical implication for government, policy makers, regulators, SMEs owner-managers and other stakeholders to recognize government support as it affects SMEs performance. The study further add to the frontier of knowledge on the importance of GSPs in strengthen the relationship between the variables and SMEs performance. This is the first study that focuses on testing the moderating role of government support policy on the relationship between entrepreneurial orientation, technology orientation and SMEs performance in Nigeria,
\end{abstract}

(C) 2017 The authors, under a Creative Commons AttributionNonCommercial 4.0

Corresponding author's email address: botulbe@gmail.com

Recommended citation: Ibrahim, M. I. Keat, O. Y. and Abd Rani, S. H., (2017)Entrepreneurial Orientation, Technology Orientation and Small and Medium Enterprises Performance in Nigeria: Role of Government Support Policies.Journal of Business and Social Review in Emerging Economies, 3 (1), 75-84.

DOI:https://doi.org/10.26710/jbsee.v3i1.44

\section{Introduction}

Small and Medium Enterprises (SMEs) formed the majority of the industrial base and contribute significantly to the societal as well as economic growth of both developed and developing countries (Ogunsiji \& Ladanu, 2010). SMEs constitute 99 percent of the total established businesses and provides gainful employment for about 90 percent of workforce in Nigeria (Okeke, Onuorah, \& Jakpa, 2016).SME sector have immensely contributed to growth of the nations' economy, wealth creation, industrial development and employment generation (Osotimehin, Jegede, Akinlabi, Olajide, 2012; World Bank, 
2014). The potentials of SMEs are exhibited in their labour-intensive nature, especially in the areas of regional income generation, poverty eradication, capital saving capacities, wealth creation, innovativeness, supply of local raw material, supporting larger industries, actualising women and youth potentials and linkage with other sectors of the economy (Iweka, Babajide, \& Olokoyo, 2016). This essentially expound the reason why SMEs are priority of government and policy makers around the world (Fashoyin, 2012; Jerven, Kale, Duncan, \& Nyoni, 2015; Osunde, 2014)

The catalytic roles of SMEs have been exhibited in advanced nations such as USA, UK and emerging nation of India Malaysia, South Africa, and Nigeria among others. SMEs in those countries have contributed considerably to the total business formation and GDP (ACCA, 2016; NBS \& SMEDAN, 2013). Therefore, regardless of the nation's status, SMEs play a significant part in contributing to the economy, particularly in the areas of innovation, social cohesion and regional development (Bouri et al., 2011).

In Nigeria, various successive administrations of government at different times have geared their efforts towards boosting the performance of SMEs. Several policy measures and financial assistance instruments were introduced(Eniola, Entebang, \& Sakariyau, 2015; Eze, Eberechi, Chibueze, Osondu, \& Ayegba, 2016). Consequently, the government of Nigeria in collaboration with international agencies had formulated and implemented policies and programs that center on financing, training and the provision of infrastructure for SMEs to improve their performance (Ogunsiji \& Ladanu, 2010).

\section{Literature Review and Hypotheses Development}

Small and medium enterprises development is globally considered as one of the most essential issues in recent years. SMEs are important not only in advance countries but also in an emerging economies as they play a greater role in the areas of employment generation, poverty reduction, promotion of innovation, competitiveness and social cohesion (Kraja, Osmani, \& Molla, 2014; Osotimehin, Jegede, Akinlabi, \& Olajide, 2012). SMEs help strengthen large enterprises by providing raw materials, services, ideas and processes, as the survival of large enterprises depends on the growth of SMEs (Shariff, Peou, \& Ali, 2010). As an emerging nation,the development of SMEs are very vital for the Nigerian economy, especially with the current dwindling of petroleum product price in the global market (Berg \& Fuchs, 2013; Taiwo, Falohun, \& Agwu, 2016).

Furthermore, in emerging nations at the same level of development with Nigeria, SMEs contributes immensely to their GDP than what is currently observed in Nigeria. This can be attributed to lack of commitment in building a strong SME sector, difficulty in sourcing finance and financial incentives, near absence of basic and technological infrastructure, inadequate legal and regulatory framework, and a commitment to building domestic expertise and knowledge (Olayiwola \& Okodua, 2013; Oyelaranoyeyinka, 2010).Therefore, in Nigeria, the development of the SME sector is not only a key issue for industrial development, but also for the socio-economic advancement of the nation and in light of recent events in the Nigerian macroeconomic environment and the central government commitment, SMEs have compelling growth potential and like other emerging economies are likely to constitute a significant portion of GDP in the near future.

The concept entrepreneurship and its influence on the growth of nation's economy is increasingly attracting the attention of researchers over the past decades. Entrepreneurship comprises activities of organizational formation and rejuvenation occurring within and outside an existing organization (Ho, Plewa, \& Nhat, 2015; Shan, Song, \& Ju, 2015; Solomon, 2017). However, in the last three decades, management researchers have mainly focused on the area of entrepreneurial orientation (EO) and firm performance (Cadogan, Boso, Story, \& Adeola, 2016; Magaji et al., 2017). Rauch, Wiklund, Lumpkin and Frese (2009) emphasized that EO signifies a promising area for building a cumulative body of relevant knowledge in the field of entrepreneurship, especially, EO has attracted a momentous attention and become an essential construct within strategic management literature. 
EO can be describe as a managerial decision- making processes, practice, style and behaviors that provide organizations with a basis for entrepreneurial decisions and actions which leads to "entry" in to new or established markets with new or existing products (Shan et al., 2015; Yoon \& Solomon, 2017).EO constructs emerges from the early work of Miller (1983) has having three characteristics of innovativeness, proactiveness and risk-taking presented as composite dimension approach by Covin and Slevin (1989). Additionally, Lumpkin and Dess (1996) conceptualized EO as multi-dimensional approach characterized by innovativeness, proactiveness, risk-taking autonomy and competitive aggressiveness, which vary independently depending on the external and internal context. Most of prior researches on EO uses the three dimensions of EO. But such an approach does not adequately represent the various factors involved in entrepreneurial processes and their varying impact on performance outcomes (Shan et al., 2015; Song \& Jing, 2017). ). Hence, in this study we employ the five dimensions to examine EOperformance relationships.

The possible role of EO as a vector of performance has been extensively examined by previous scholars and a number of studies have found an inconsistent relationship between EO and performance (AlDhaafri, Al-Swidi, \&Yusoff, 2016). Some of the prior studies established a positive relationship between EO and firm performance (Magaji et al., 2017; Ogunsiji \& Ladanu, 2010; Shan et al., 2015; Song \& Jing, 2017). Others found EO as having a negative bearing on firm performance (Hartsfield, Johansen, \& Knight, 2008; Kreiser, Marino, Kuratko, \& Weaver, 2013; Stam \& Elfring, 2008). While some others advanced a curvilinear relationship between EO and firm performance (Cadogan et al., 2016; Tang, Tang, Marino, Zhang, \& Li, 2008; Yoon \& Solomon, 2017). Thus, this study contend that a there is a relationship between EO and firm performance.

H1. A significant relationship exist between entrepreneurial orientation and performance of SMEs.

As one of the most important strategic orientations used by firms to achieve a long-term business success, technology orientation (TO) is a managerial approach that stresses the application of technologies in both products and operational procedures (Kapoor \& Lee, 2010; Pratono, 2016; Song \& Jing, 2017). TO can be described as the extent to which firms emphasize on acquiring and applying sophisticated technologies in new product development and improving on existing products that often linked with entrepreneurial firm performance that encourages openness to new ideas, creative thinking and proactive in initiating appropriate actions (Deshpande, Grinstein, Snow, \& Elie, 2013; Kasim \& Altinay, 2016; Odondo, Okibo, \& Odhiambo, 2017). TO predominantly focus on technology by pursuing state-of-the art technologies to improve and develop new products, openness to new ideas and prefer such ideas that employ the most advance technologies (Zhou \& Li, 2010).

Previous studies have advanced a significant relationship between TO and firm performance which shows TO positively impacting on performance and profitability of SMEs (Amirkhani \& Reza, 2015; Di Benedetto, 2011; Pratono, 2016a; Zhou \& Li, 2010). In a similar studies, Spanjol, Qualls and Rosa (2011) found TO as having a significantly positive effect on product performance especially in terms of branding, quality and newness of product to customers. On the contrary, Deshpande et al. (2013)in their studies on strategic orientations and firm performance, found no significant effect of TO on both subjective and objective performance of a firm. Gao et al. (2007) study the effect of customer orientation, competitor orientation and TO in a transitional economy. Their study discloses the fact that TO positively affect firm profitability and product performance with an average technological changes, while it has no significant effect on sales growth. Though, the study indicated that with little technological instability, TO will have a negative effect on firm performance.

Furthermore, Halaka and Kohtamaki (2010)examined the interplay between EO, TO, customer orientation and company performance of 164 software companies, the results show that TO has no direct significant relationship with performance. Nevertheless, Halaka and Kohtamaki (2011) supported the evidence that 
firms converging several strategic orientations perform better than those focusing solely on a single strategic orientation. Though, TO is not linked with environmental hostility and dynamism to the same extent as EO, nevertheless, a lot of potential exists in emerging countries toimport and adapt technologies developed in the advanced countries. A cavernous and thorough understanding of EO, TO, and environmental conditionsis essential not only for academic purposes but also because the subjecthas salience for practitioners and policy-makers (Urban \& Barreria, 2010). According toUrban and Barreria (2010) and Zhou and Li (2010), businesses that adopt TO can accumulate rich technological awareness that can improve their adaptive capability. Based on inconsistent findings from previous studies, the following hypothesis is postulated:

$\mathrm{H} 2$. A significant relationship exist between technology orientation and performance of SMEs

Government support on SMEs are policies designed by government and their regulatory agencies to regulate and guide decisions making process that foster economic development by creating environment that is adequately protected for business operations, especially, SMEs (Wakili, 2016). Osinbajo (2015)highlighted that Nigerian economy is faced by serious challenges due to negligence in SMEs sector for over four decades. Hence, the problem is a matter of grave concern to the Nigerian government and other stakeholders. The central government of Nigeria introduced new policies aims at encouraging the indigenous SMEs to strengthen their market potentials and subsequently improve their productivity and performance (Omonobi \& Bivbere, 2016). Consequently, the government of Nigeria resolves to engage more with SMEs and entrepreneurial activities towards ensuring viable economic development and wealth creation by supporting the sector (Osinbajo, 2015). In view of the current government's commitment therefore, this study examines the moderating effect of government support in strengthening the relationship between EO and TO on SMEs performance in Nigeria hence, postulated the following hypotheses.

H3: Government support moderates the relationship between EO and performance of small and medium enterprises

H4: Government support moderates the relationship between TO and performance of small and medium enterprises.

\section{Methodology}

This section discoursed the method of data collection and the technique adopted in analyzing the data. A survey method with structured questionnaire was utilized to collect data from SME owner-managers in northeast Nigeria. Zahra and Covin (1995) asserted that in a study related to SMEs, usually the ownermanagers are the target respondents given that they have more knowledge regarding their companies' strategies and overall business situations. This is in conformity with previous studies (see Lechner\&Gudmundsson, 2012).

The sample for the study was selected by using stratified random sampling were the population embraces a number of distinct categories. The sample was then organized by these categories into separate strata and each stratum was sampled as an independent sub-population, out of which individual elements were randomly selected. Similarly, constructs of the study were measured using questionnaires adapted from previous studied and modified to suit Nigerian context. The items on EO was adapted from Covin and Wales (2011), TO items adapted from Halaka and Kohtomaki (2011), government support items adapted from Chea (2009) while SME performance items were adapted from Suliyonto and Rehab (2012) all measured with 7 point-likert scale. According to NBS and SMEDAN (2013) annual report, the northeast region of Nigeria has 8,662 registered SMEs. This formed the target population of this study, hence, the sample size for the target population according to Dillman (2007) formula is 368. From the sample size, two hundred and forty (240) usable questionnaires went for final analysis, yielding a $56 \%$ response rate. SPSS 22v and PLS-SEM 2.0 were used to test the validity and reliability of the items and to test the hypotheses of the study. 


\section{Data analysis and Findings.}

An initial test of validity and reliability using smart PLS 2.0 was conducted. The framework for the study has two independent variables namely entrepreneurial orientation (EO) and technology orientation (TO) which represent a firm valuable, rare, inimitable and non-substitutable (VRIN) resources and capabilities as signified by the RBV theory. The dependent variable is firm performance (SME) and government support is the moderating variable.

To assess the measurement model for the study, constructs validity and reliability of specific items measuring each latent construct were carried out, discriminant validity, as well as convergent validity for each of reflective constructs (SME performance and government support) were also evaluated in order to determine the accurateness of the measurement (Hair, Hult, Ringle, \& Sarstedt, 2014). After calculating PLS algorithm, the next action was to assess the indicators reliability to see if there is any item indicator with loading less than 0.4 so as to delete them from the model. As all the items indicators met the requirement as presented in Tables 1 and 2, there is no case for deletion. Additionally, as recommended by Hair, Ringle and Sarstedt (2011), the composite reliability for internal consistency reliability of all constructs meet the condition ranging from 0.7 and 0.8 respectively. Equally, the average variance extracted (AVE) for convergent validity of all the constructs are considered accepted as all the AVE meet the minimum threshold of 0.5 as recommended by (Hair jr, Sarstedt, Hopkins, \& Kuppelwieser, 2014). In conclusion, to justify the discriminant validity the square root of AVE is compared to correlation square of the interrelated variables of concern constructs which indicates adequate discriminant validity.

Table 1: Factor Loadings, CR and AVE

\begin{tabular}{lccc}
\hline Items & Loadings & CR & AVE \\
\hline GSP1 & 0.8909 & 0.9688 & \\
GSP10 & 0.9034 & & \\
GSP11 & 0.8236 & & \\
GSP12 & 0.8352 & \\
GSP13 & 0.8652 & \\
GSP2 & 0.8422 & \\
GSP3 & 0.7949 & \\
GSP4 & 0.8386 & \\
GSP5 & 0.8636 & \\
GSP6 & 0.8392 & \\
GSP7 & 0.8082 & \\
GSP8 & 0.7841 & \\
GSP9 & 0.8168 & \\
PER1 & 0.8773 & \\
PER10 & 0.8901 & \\
PER2 & 0.9083 & \\
PER3 & 0.9034 & \\
PER4 & 0.8918 & \\
PER5 & 0.9008 & \\
PER6 & 0.794 & \\
PER7 & 0.8303 & \\
PER8 & 0.9128 & \\
PER9 & 0.8999 & \\
TO1 & 0.8923 & \\
TO10 & 0.9011 & \\
TO2 & 0.8917 & \\
TO3 & 0.8645 & \\
TO4 & 0.8749 & \\
TO5 & 0.8771 & \\
TO6 & 0.8973 & \\
TO7 & 0.8831 & \\
TO8 & 0.8904 & \\
& & \\
\end{tabular}


Table 2: Discriminant validity

\begin{tabular}{llll}
\hline Constructs & GSP & SME PER & TO \\
\hline GSP & 48.99 & & \\
SME PER & 0.45 & 0.00 & 0.00 \\
TO & 0.80 & 0.54 & \\
\hline
\end{tabular}

Similarly, to ascertain the formative construct (EO), the researchers have examined two conditions upon each indicator to determine whether they are significant in or not. As shown in Table 3, first was to assess the collinearity among the indicators using variance inflation factor (VIF) values, the threshold of which should not be more than 5 . The second condition is to assess the significance of the statistical contribution of each formative indicator to the main construct.

Table 3: Assessment of Collinearity and significance relevance of formative construct

\begin{tabular}{lccccc}
\hline Construct & Dimensions & VIF & Outer Weight & Outer Loadings & T-statistics \\
\hline \multirow{3}{*}{ EO } & AUT & 4.08 & 0.09 & 0.91 & 0.35 \\
& CA & 3.82 & 0.36 & 0.93 & 1.5 \\
& INNO & 4.83 & 0.5 & 0.96 & 1.48 \\
& PRA & 4.52 & 0.26 & 0.93 & 0.88 \\
RT & 4.55 & 0.17 & 0.85 & 0.74 \\
\hline
\end{tabular}

After satisfying all the requirements for the measurement model, the next section presents the structural model of the analysis through the standard bootstrapping method using 5,000 bootstrap sample for 240 dataset to ascertain the significance levels of the direct and moderating relationships (Hair et al., 2014). These include the hypotheses testing, evaluation of R-square, effect size and predictive relevance.

Table 4: Hypotheses for direct relationship

\begin{tabular}{lccccc}
\hline Hypotheses & Beta & Std Error & T value & P-value & Decision \\
\hline EO -> SME PER & 0.23 & 0.11 & 2.18 & 0.03 & Supported \\
TO -> SME PER & 0.34 & 0.10 & 3.30 & 0.00 & Supported \\
\hline
\end{tabular}

Table 4 presents direct relationship between independent variables and the dependent variable. The findings for the relationship between EO and SME-PER reveals a positive relationship $(\beta=0.23, \mathrm{SE}=$ $0.11, \mathrm{TV}=2.18$ ). This result is consistent with (Kreiser, Marino, Kuratko, \& Weaver, 2013; NaranjoValencia et al., 2016), which are all positively significant. Therefore, hypothesis one is supported. Similarly, TO and SEM-PER is positively significant $(\beta=0.34, \mathrm{SE}=0.10, \mathrm{TS}=3.30)$. This also confirmed with prior studies ((Amirkhani \& Reza, 2015; Di Benedetto, 2011; Pratono, 2016a; Zhou \& Li, 2010), they found TO as positively related to PER. In this case, EO and TO practices of SMEs have significant influence on PER. Therefore hypothesis two cannot be rejected.

Table 5: Moderation Hypotheses

\begin{tabular}{lccccc}
\hline Hypotheses & Beta & Std Error & T values & P-value & Decision \\
\hline EO * GSP -> SME PER & 0.34 & 0.15 & 2.25 & 0.03 & Supported \\
TO * GSP -> SME PER & 0.29 & 0.13 & 2.17 & 0.03 & Supported \\
\hline
\end{tabular}

Table 5, provides the moderating effect of GSP on the relationship between EO and SME PER. The results indicates a positive moderating effect by providing $(\beta=0.34, \mathrm{SE}=0.15$, TS $=2.25)$. While, GSP positively moderates the relationship between TO and SME PER at $(\beta=0.29, \mathrm{SE}=0.13, \mathrm{TS}=2.25)$. this result is consistent with (Shariff et al., 2010). Consequently, hypotheses three and four are supported. 
Table 6: Predictive relevance Moderation Model

\begin{tabular}{lccc}
\hline Total & SSO & SSE & 1-SSE/SSO \\
\hline SME PER & 2400 & 1814.20 & 0.24 \\
\hline
\end{tabular}

Table 7: Effect size $\left(\mathbf{f}^{2}\right)$ and $\mathbf{R}$-squared $\left(\mathbf{R}^{2}\right)$ for Moderation Model

\begin{tabular}{lcccc}
\hline Moderation & Included & Excluded & f-squared & Effect size \\
\hline R-squared & 0.32 & 0.31 & 0.018 & None \\
\hline Moderation R-square & & & & \\
\hline Construct & & & R-square $\left(\mathbf{R}^{2}\right)$ \\
\hline SME PER & & & 0.32 \\
\hline
\end{tabular}

The essence of evaluating the predictive relevance in PLS-SEM is to accurately predict the data points of indicators in reflective measurement model of endogenous construct and endogenous single-item. In view with this argument, the predictive relevance of the model shows 0.24 which is above the threshold. A $\mathrm{Q}^{2}$ value higher than zero for a certain reflective endogenous latent variable indicates the path model's predictive relevance for a particular constructs as significant (Hernández-erlines, Moreno-García, \&Yañez-Araque, 2016). According to Sarstedt, Ringle, Henseler, and Hair (2014), a predictive relevance of $0.35,0.15$ and 0.02 are large, medium and small respectively. Consequently, in line with these submissions, the model of this study has a medium predictive relevance.

Likewise, the $\mathrm{R}^{2}$ included is 0.321 as well as $\mathrm{R}^{2}$ excluded is 0,311 for the two independent variable (EO and TO), thus, contributed $32 \%$ to the model. Similarly, $\mathrm{f}^{2}$ value is 0.018 which predicts none effect size for the constructs. However, according to Chin, Marcolin, and Newsted (2003) an $\mathrm{f}^{2}$ above zero can be meaningful under extreme moderation condition. The results of the study validate that government support policy act as a moderator to strengthen the relationship between EO, TO and SMEs performance in Nigeria.

\section{Conclusion}

The objective of this study is mainly to examine the relationship between EO and TO on the performance of SMEs in Nigeria and to determine the extent to which government support can strengthen the relationship for a greater performance. Government support was espoused as a moderating variable in line with suggestions by previous studies (Egena et al., 2014; Eze et al., 2016; Shariff et al., 2010).This study confirmed that GSPs as a dynamic moderating factor have a potential influence on the relationship between EO, TO and performance of SMEs in Nigeria.In this regards, SMEs in Nigeria are inspired to combine their intangible internal resources such as EO and TO with intangible external resource (GSPs) in order to realize a competitive advantage that translate into firm performance and profitability. The study further tested empirically, the relationship between EO and TO on SMEs performance. The conclusion drawn from the results of this study should consider the limitation of regional bias, as the sample consists 8,662 SMEs in northeast Nigeria from which the sample is drawn, which may not necessarily represent the entire population.

Likewise, there is a baffling but vital factors that should be integrated to ascertain the causal relationship among variables and their relative explanatory power. Directions for further studies should consider the SMEs characteristics for further exploration; this may provide meaningful perspectives for understanding how individual similarities and differences affect SMEs performance. Equally, the future studies should consider a longitudinal approach to describe the changes and the directions, and extent of underlying relationships between variables.

\section{References}


ACCA, I. R. (2016). Building for the future. ACCA Publishers London.

Aminu, I. M., \& Shariff, M. N. M. (2014). The relationship between entrepreneurial orientation , market orientation , learning orientation, technology orientation and SMEs performance in Nigeria, 108-116. Retrieved from repo.uum.edu.my

Amirkhani, A. H., \& Reza, A. M. (2015). Investigating the Relationship between Strategic Orientation and Firm 's Performance Considering the Intermediary Role of Business Strategy. Journal of Management Sciences., 1(8), $152-157$.

Barney, J. B. (1986). Organization Culture: Can it be a Source of Sustained Competitive Advantage? Academy of Management Review, 11(3), 656-665.

Berg, G., \& Fuchs, M. (2013). Bank Financing of SMEs in Five Sub-Saharan African Countries The Role of Competition, Innovation, and the Government, (August).

Bo, Z., \& Qiuyan, T. (2012). Research of SMEs' Technology Innovation Model from Multiple Perspectives. Chinese Management Studies, 6(1), 124-136.

Bouri, A., Breji, M., Diop, M., Kempner, R., Klinge, B., \& Stevenson, K. (2011). Report on Support to SMEs in Developing Countries Through Financial Intermediaries. Washington DC.

Cadogan, J. W., Boso, N., Story, V. M., \& Adeola, O. (2016). Export strategic orientation - performance relationship: Examination of its enabling and disenabling boundary conditions 㑱. Journal of Business Research. http://doi.org/10.1016/j.jbusres.2016.04.078

Covin, J. G., \& Slevin, D. P. (1989). Strategic Management of Small Firms in Hostile and Benign Environments. Strategic Management Journ, 10(1), 75-87. Retrieved from http://www.jstor.org/stable/24863

Deshpande, R., Grinstein, A., Snow, K., \& Elie, O. (2013). Achievement motivation, strategic orientations and business performance in entrepreneurial firms How different are Japanese and American founders? International Marketing Review, 30(3), 231-252. http://doi.org/10.1108/0265133131132198

Egena, O., Wombo, D. N., Theresa, E. E., \& Bridget, M. N. (2014). Institutional Support for Small and Medium Enterprises in Nigeria: An Empirical Investigation. International Journal of Economy, Management and Social Sciences, 3(9), 481-489.

Eniola, A. A., Entebang, H., \& Sakariyau, O. B. (2015). Small and medium scale business performance in Nigeria : Challenges faced from an intellectual capital perspective. International Journal of Research Studies in Management, 4(1), 59-71.

Eze, N. M., Eberechi, O. O., Chibueze, A. Z., Osondu, N. M., \& Ayegba, S. F. (2016). Funding Arrangements for Small and Medium Scale Enterprises (SMEs) in Nigeria,. Journal of Business Theory and Practice, 4(1), 124. Retrieved from www.scholink.org/ojs/index.php/jbtp

Fashoyin, T. (2012). The Youth Employment Challenge in Nigeria. E-Journal of International and Comparative Labour Studies, 1(3), 1-10.

Finney, R. Z., Lueg, J. ., \& Campbell, N. . (2008). Market Pioneers, Late Movers and the Resource-Based View (RBV): A Concptual Model. Journal of Business Research, 61(9), 925-932.

Gao, G. Y., Zhou, K. Z., \& Yim, C. K. (B ). (2007). On what should firms focus in transitional economies? A study of the contingent value of strategic orientations in China. International Journal of Research in Marketing, 24(1), 3-15. http://doi.org/10.1016/j.ijresmar.2006.09.004

Gatington, H., \& Xuereb, J.-M. (1997). Strategic orientation of the firm and new product performance. Journal of Marketing Research, 1-46.

Hair, J. F., Hult, G. T. M., Ringle, C., \& Sarstedt, M. (2014). A Primer on Partial Least Squares Structural Equation Modeling (PLS-SEM) (Vol. 46). USA: SAGE Publication. http://doi.org/10.1016/j.lrp.2013.01.002

Hair, J. F., Ringle, C. M., \& Sarstedt, M. (2011). PLS-SEM: Indeed a Silver Bullet. Journal of Marketing Theory and Practice, 19(2), 139-153.

Hair jr, j. F., Sarstedt, M., Hopkins, L., \& Kuppelwieser, V. G. (2014). Partial least squares structural equation modeling(PLS-SEM): An emerging tool in business research. European Business Review, 26(2), 106-121.

Halaka, H., \& Kohtamaki, M. (2010). The interplay between orientations: Entrepreneurial, technology and customer orientations in software companies. Journal of Enterprising Culture., 18(3), 265-290.

Halaka, H., \& Kohtamaki, M. (2011). Configurations of entrepreneurial- customer- and technology orientation Differences in learning and performance of software companies. International Journal of Entrepreneurial Behaviour \& Research, 17(1), 64-82. http://doi.org/10.1108/13552551111107516

Hartsfield, S., Johansen, D., \& Knight, G. A. (2008). Entrepreneurial orientation , strategy, and marketing capabilities in the performance of born global firms.International Business: Research Teaching and Practice Journal of the AIB-SE, 2(1), 12-38.

Ho, J., Plewa, C., \& Nhat, V. (2015). Examining strategic orientation complementarity using multiple regression 
analysis and fuzzy set QCA 次. Journal of Business Research. http://doi.org/10.1016/j.jbusres.2015.12.030 Hooley, G. J., Greenley, G. E., Cadogan, J. W., \& Fahy, J. (2005). The performance impact of marketing resources. Journal of Business Research, 58(1), 18-27. http://doi.org/10.1016/S0148-2963(03)00109-7

Iweka, H., Babajide, A., \& Olokoyo, F. O. (2016). Dynamics of Small Business in an Emerging Market: Challenges and Opportunities. In 3rd International Conference on African Development Issues (pp. 91-99).

Jerven, M., Kale, Y., Duncan, M. E., \& Nyoni, M. (2015). GDP Revisions and Updating Statistical Systems in SubSaharan Africa: Reports from the Statistical Offices in Nigeria, Liberia and Zimbabwe. The Journal of Development Studies, 1-16. http://doi.org/10.1080/00220388.2014.968139

Kapoor, R., \& Lee, J. M. (2010). Coordinating and competing in ecosystems: How organizational forms shape new technology investments. Strategic Management Journal, 34(3), 274-296. http://doi.org/10.1002/smj.2010

Kasim, A., \& Altinay, L. (2016). How do Technology Orientation , Organizational Learning , Market Conditions , and firm Growth Connect? A Preliminary Analysis on Small and Medium Size Hotels in Peninsular, 6(Mc), 121-126.

Kraja, Y. B., Osmani, E., \& Molla, F. (2014). The Role of the Government Policy for Support the SME-s. Academic Journal of Interdisciplinary Studies, 3(2), 391-396. http://doi.org/10.5901/ajis.2014.v3n2p391

Kreiser, P. M., Marino, L. D., Kuratko, D. F., \& Weaver, K. M. (2013). Disaggregating entrepreneurial orientation : the non-linear impact of innovativeness, proactiveness and risk-taking on SME performance. Journal of Small Business and Economics, 40, 273-291. http://doi.org/10.1007/s11187-012-9460-x

Li, J. J., \& Zhou, K. Z. (2005). The Formation of Managerial Networks of Foreign Firms in China: The Effects of Strategic Orientations. Institute for the Study of Business Markets. http://doi.org/10.1007/s10490-005-4118-8

Lumpkin, G. T., \& Dess, G. G. (1996). Clarifying the Entrepreneurial Orientation Construct and Linking it to Performance. The Academy of Management Review, 21(1), 135-172. Retrieved from http://www.jstor.org/stable/258632

Magaji, M. S., Baba, R., \& Entebang, H. (2017). Entrepreneurial Orientation and Financial Performance of Nigerian SMES : The Moderating Role of Environment . A Review of Literature. Journal of Management and Training for Industries, 4(1), 25-42. http://doi.org/10.12792/JMTI.4.1.25

Miller, D. (1983). The Correlates of Entrepreneurship in Three Types of Firms. MANAGEMENT SCIENCE, 29(7), 770-791.

Mu, J., \& Di Benedetto, C. A. (2011). Strategic Orientations and New Product Commercialization: Mediator, Moderator, and interplay. $R \& D$ Management, 41(4), 337-359.

NBS, \& SMEDAN. (2013). Smedan and National Bureau of Statistics Collaborative Survey: Selected Findings. Abuja, Nigeria.

Odondo, M. O., Okibo, W. B., \& Odhiambo, P. R. (2017). Effect of Technology Orientation on Performance of Micro , Small and Medium- Scale Agro-Food Processing Enterprises in Nairobi County , Kenya, (1), 483494.

Ogunsiji, A. S., \& Ladanu, K. W. (2010). Entrepreneurial Orientation as a Panacea for the Ebbing Productivity in Nigerian Small and Medium Enterprises: A Theoretical Perspective. International Business Research, 3(4), 192-199.

Okeke, M. N., Onuorah, A. N., \& Jakpa, U. G. (2016). Impact of strategic management on the performance of small and medium enterprises.Global Journal of Applied, Management and Social Sciences, 11(2), 57-66.

Olayiwola, K., \& Okodua, H. (2013). Foreign Direct Investment , Non-Oil Exports , and Economic Growth in Nigeria : A Causality Analysis. Asian Economic and Financial Review., 3(11), 1479-1496.

Omonobi, K., \& Bivbere, G. (2016). Customs Re-imposed Ban on Rice Importation. Retrieved May 6, 2016, from http://www.vanguardngr.com/2016/03/customs-re-imposes-ban-rice-importation/

Osinbajo, Y. (2015). Federal Government and United State to Support SMEs with Funding. Retrieved May 20, 2015, from http://www.firstafricanews.ng

Osotimehin, K.O., Jegede, Charles. A, Akinlabi, Babatunde. H, Olajide, O. T. (2012). An Evaluation of the Challenges and Prospects of Micro and Small Scale Enterprises Development in Nigeria Department of Business Administration and Management Technology Lagos State University External System. American International Journal of Contemporary Research, 2(4), 174-185.

Osunde, C. (2014). Entrepreneurs and Entrepreneurship in Developing Countries: The Nigerian Experience. The Standard International Journals, 2(2), 26-32.

Oyelaran-oyeyinka, B. P. B. (2010). Financial System Strategy FSS 2020 International Conference SME: Issues, Challenges and Prospects. In FSS International Conference (pp. 1-39). Abuja, Nigeria.

Penrose, E. T. (1959). Theory of Growth of the Firm. New York: John Wiley \& Sons. 
Pratono, A. H. (2016). Strategic Orientation and Information Technological Turbulence: Contingency Perspective in SMEs. Business Process Re-Engineering \& Management Journal, 22(2), 50-65. http://doi.org/10.1108/14637150210449102

Rauch, A., Wiklund, J., Lumpkin, G. ., \& Frese, M. (2009). Entrepreneurial orientation and business performance: an assessment of past research and suggestions for the future.Entrepreneurship Theory and Practice, 33(3), 761-787. Retrieved from http://www.blackwellpublishing.com/journal.asp?ref=1042-2587\&site=1

Shan, P., Song, M., \& Ju, X. (2015). Entrepreneurial orientation and performance: Is innovation speed a missing link? Journal of Business Research. http://doi.org/10.1016/j.jbusres.2015.08.032

Shariff, M. N. M., Peou, C., \& Ali, J. (2010). Moderating Effect of Government Policy on Entrepreneurship and Growth Performance of Small-Medium Enterprises in Cambodia. International Journal of Business and Management Science, 3(1), 57-72.

Song, L., \& Jing, L. (2017). Strategic orientation and performance of new ventures : empirical studies based on entrepreneurial activities in China. International Entrepreneurship and Management Journal. http://doi.org/10.1007/s11365-017-0433-z

Spanjol, J., Qualls, W. J., \& Rosa, J. A. (2011). How many and what klind? The role of strategic orientation in new product ideation. Journal of Product Innovation Management, 28(2), 236-250. http://doi.org/10.1111/j.15405885.2010.00794.x

Stam, W., \& Elfring, T. O. M. (2008). Entrepreneurial Orientation and New Venture Performance : the Moderating Role of Intra- and Extraindustry Social Capital. Academy of Management Journal, 51(1), 97-111. http://doi.org/10.5465/AMJ.2008.<strong>30744031</strong>

Taiwo, J. N., Falohun, T. O., \& Agwu, E. M. (2016). Smes financing and its effects on nigerian economic growth. European Journal of Business, Economics and Accountancy, 4(4), 37-54.

Tang, J., Tang, Z., Marino, L. D., Zhang, Y., \& Li, Q. (2008). Exploring an Inverted U-Shape Relationship between Entrepreneurial Orientation and Performance in Chinese Ventures. Entrepreneurship Theory and Practice, 32(1), 219-239.

Urban, B., \& Barreria, J. (2010). Empirical Investigations Into Firm Technology Orientation and Entrepreneurial Orientation. International Journal of Innovation and Technology Management, 7(4), 329-351. http://doi.org/10.1142/S0219877010001969

Wakili, I. (2016). Nigeria Can Survive without Oil. Retrieved June 28, 2016, from http://www.dailytrust.com.ng/news/general/nigeria-can-survive-without-oil-osinbajo/131850.html

World Bank. (2014). Nigeria Economic Report: Improved Economic Outlook in 2014, and Prospects for Continued Growth Look Good. Retrieved September 12, 2015, from http://www.worldbank.org/en/country/nigeria/publication/nigeria-economic-report-improved-economicoutlook-in-2014-and-prospects-for-continued-growth-look-good

Yoon, J., \& Solomon, T. (2017). A curvilinear relationship between entrepreneurial orientation and firm performance: The moderating role of employees ' psychological safety. International Entrepreneurship and Management Journal, 1-18. http://doi.org/10.1007/s11365-017-0448-5

Zhou, K. Z., \& Li, C. B. (2010). How strategic orientations influence the building of dynamic capability in emerging economies. Journal of Business Research, 63(3), 224-231. http://doi.org/10.1016/j.jbusres.2009.03.003

Ziaul Hoq, M. (2009). Innovativeness : Its Antecedents and Impact on SME Business Performance. International Journal of Business and Management, 4(11), 100-110. 